\title{
IgG subclass deficiency in asthma
}

\author{
B G LOFTUS,$*$ J F PRICE, ${ }^{*}$ A LOBO-YEO,$\dagger$ AND D VERGANI $\dagger$ \\ ${ }^{*}$ Departments of Child Health and †Immunology, King's College School of Medicine and Dentistry, London
}

SUMmary Total immunoglobulin $\mathrm{G}(\mathrm{IgG})$ and subclasses were measured in serum samples from 82 children with chronic asthma, aged 1.5 to 6.3 years, and 76 controls. Concentrations of $\operatorname{IgG}_{1}$, $\mathrm{IgG}_{2}, \mathrm{IgG}_{3}$, and total $\mathrm{IgG}$ were significantly lower in asthmatic children aged 1 to 5 , and $\operatorname{IgG}_{2}$ concentrations were also significantly lower in asthmatic children over 5 years of age. Twenty eight asthmatic children had at least one value in the deficient range, and 26 had $\mathrm{IgG}_{2}$ deficiency alone or in combination. Five children had $\operatorname{IgG}_{2}$ and $\operatorname{IgA}$ deficiency. These 28 children were significantly younger and fewer had raised IgE concentrations than the remainder.

IgG subclass deficiency, which may reflect delayed maturation of the immune system, is common in young asthmatic children, and may have a role in the pathogenesis of the disease.

The importance of respiratory infection in precipitating attacks of asthma is well known. Deficiencies of IgG limited to one or more subclasses have been recognised in children with recurrent infections ${ }^{1}$ and one small study found evidence of $\mathrm{IgG}$ subclass deficiency in 'non-allergic children with chronic chest symptoms'. ${ }^{2}$ Because other forms of immunodeficiency have been associated with atopic diseases, we decided to study IgG subclass concentrations in a large group of chronic asthmatic children.

\section{Patients and methods}

We studied 82 children with chronic asthma, all of whom were attending the paediatric respiratory clinic at King's College Hospital. Children were included if they had asthma severe enough to warrant regular bronchodilators or prophylactic medication-that is, at least one severe attack a month, or symptoms on most days. Fifty six boys and 26 girls aged 1.5 to 6.3 years were recruited. The first symptoms of asthma occurred under the age of 1 year in 36, and under the age of 2 in 69 . Half the children had symptoms of rhinitis, and half had present or past symptoms of eczema. Skin testing to six common allergens was carried out on 69 , and yielded one or more positive reactions in 55. Sixty six had raised serum IgE concentrations (more than two standard deviations above the age matched mean). Forty eight children required steroids by inhalation, five sodium cromoglycate, 10 theophylline, and 19 regular $\beta$ agonists. Serum samples from 76 unselected healthy controls, 38 boys and 38 girls aged 1 to 6.8 years were also analysed. These children were recruited in conjunction with the Michael McGough Foundation; they were in good health at the time of the study and had no history of serious disease.

We compared values for male and female controls to determine whether there was any sex difference in IgG subclass concentrations. Because concentrations of IgG subclasses vary with age,${ }^{3}$ asthmatic and control children were divided in three groups 1 to 2.99 years, 3 to 4.99 years, 5 to 6.99 years, for the purposes of analysis so that age matched comparison could be carried out. In the 1-2.99 years age group there were 17 controls (eight of whom were boys) and 22 asthmatic children (15 of whom were boys); in the 3-4.99 years age group there were 22 controls (11 of whom were boys) and 42 asthmatic children ( 31 of whom were boys); and in the 5-6.99 years age group there were 37 controls (20 of whom were boys) and 18 asthmatic children (10 of whom were boys). In both asthmatic and control groups were calculated the geometric mean and ranges using logarithmic transformation of the data. ${ }^{4}$ The significance of differences between values in control and asthmatic children were assessed using Student's $t$ test and the Wilcoxon rank sum test, probabilities of less than 0.05 being accepted as significant.

Asthmatic children with abnormal concentrations of IgG subclasses were compared with the remainder for age, and clinical and atopic state. The $\chi^{2}$ test was used to assess the significance of any differences. 
IgG subclasses were measured using an enzyme linked immunosorbent assay (ELISA) based on the method described by Aucouturier et al ${ }^{5}$ The monoclonal antibodies used were: $\mathrm{IgG}_{1}$, clone NL16 (WHO/IUIS HP 6012) diluted $1 / 100 ; \mathrm{IgG}_{2}$, a mixture of clone GOM2 (HP 6009) and HP 6014, diluted $1 / 100 ; \mathrm{IgG}_{3}$, clone ZG4 (HP 6010) diluted 1/1000; and $\mathrm{IgG}_{4}$, clone RJ4 (HP 6011) diluted 1/100. All monoclonal antibodies were obtained from Oxoid (Bedford, UK).

Microtitre plates were coated with purified monoclonal antibody of the relevant subclass at optimal dilution, in $0.01 \mathrm{~mol} / \mathrm{l}$ phosphate buffer, $0.15 \mathrm{~mol} / \mathrm{l}$ in sodium chloride, $\mathrm{pH} \mathrm{7.4} \mathrm{(phosphate} \mathrm{buffered}$ saline) overnight at $4^{\circ} \mathrm{C}$. Assays were conducted in triplicate in a volume of $100 \mu \mathrm{l}$ in wells of polystyrene microtitre plates (Dynatech Immulon M129B, Dynatech Laboratories Ltd, Sussex, UK). After discarding the coating solution the wells were incubated with $5 \%$ bovine serum albumin in phosphate buffered saline, for one hour at $37^{\circ} \mathrm{C}$ to block residual reactive sites on the plastic wells. The plates were then washed with casein trometamol (Tris) buffer $(0.05 \%$ casein, $0.9 \%$ sodium chloride, $0.01 \%$ thimersol, $10 \mathrm{nmol} / \mathrm{l}$ Tris hydrochloric acid, $\mathrm{pH} 7 \cdot 6)$. All washes were done with an automated plate washer (Dyantech Autowash 2000). Patient or control serum was added at a dilution of $1 / 40$ in phosphate buffered saline containing $1 \%$ bovine serum albumin and incubated for two hours at $37^{\circ} \mathrm{C}$. A standard curve was established for each subclass using a reference serum preparation SPS-01 (Royal Hallamshire Hospital, Sheffield). After a further wash with casein Tris buffer, a peroxidase conjugated goat antihuman IgG anti'body (Tago Inc) diluted $1 / 1000$ in phosphate buffered saline was added and incubated for 1.5 hours at $37^{\circ} \mathrm{C}$. After a final wash with phosphate buffered saline, the peroxidase activity of each well was determined with the colorimetric substrate, O-Phenylenediamine $(0.4 \mathrm{mg} / \mathrm{ml})$ and the reaction stopped with $2 \mathrm{~mol} / \mathrm{l}$ sulphuric acid. The absorbance of the wells was determined at $490 \mathrm{~nm}$ using a Dynatech MR700 Elisa reader.

Each serum sample was studied at least twice, and a sample from a normal serum pool was included in every plate. The intra-assay coefficient of variation was $8 \%$ and the interassay coefficient of variation was $14 \%$. A good correlation between the concentrations of IgG obtained by summing subclasses and total IgG concentrations was found on measurement by laser nephelometry (linear regression analysis $r=0.89$ ).

Informed consent was obtained from all parents and the study was approved by the hospital ethical committee.
Table 1 Mean (range) IgG concentrations $(g / l)$ in the three age groupings

\begin{tabular}{|c|c|c|c|c|}
\hline & $\begin{array}{l}\text { Control } \\
\text { children }\end{array}$ & $\begin{array}{l}\text { Asthmatic } \\
\text { children }\end{array}$ & $t$ & p Value \\
\hline \multicolumn{5}{|c|}{ Age 1 to 2.99 years: } \\
\hline Total IgG & $10.04(7.4-13.7)$ & $7 \cdot 8 \quad(5 \cdot 0-12 \cdot 2)$ & $4 \cdot 16$ & $<0.01$ \\
\hline $\mathrm{G}_{1}$ & $6 \cdot 6 \quad(4 \cdot 0-10 \cdot 8)$ & $5 \cdot 5 \quad(3 \cdot 4-8 \cdot 7)$ & $2 \cdot 52$ & $<0.05$ \\
\hline $\mathrm{G}_{2}$ & $2 \cdot 1 \quad(1 \cdot 6-2 \cdot 8)$ & $1.3 \quad(0.4-3.9)$ & $3 \cdot 53$ & $<0.01$ \\
\hline $\mathrm{G}_{3}$ & $0.89(0.4-1.9)$ & $0.73(0.4-1 \cdot 3)$ & & NS \\
\hline $\mathrm{G}_{4}$ & $0 \cdot 3 \quad(0 \cdot 1-0 \cdot 5)$ & $0 \cdot 2 \quad(0 \cdot 1-0 \cdot 4)$ & & NS \\
\hline \multicolumn{5}{|c|}{ Age 3 to 4.99 years: } \\
\hline Total IgG & $9 \cdot 9 \quad(6 \cdot 6-14 \cdot 9)$ & $8 \cdot 1 \quad(5 \cdot 6-11 \cdot 5)$ & $4 \cdot 26$ & $<0.01$ \\
\hline $\mathrm{G}_{1}$ & $6 \cdot 4 \quad(4 \cdot 2-9 \cdot 9)$ & $5 \cdot 5 \quad(3 \cdot 7-8 \cdot 2)$ & $2 \cdot 74$ & $<0.01$ \\
\hline $\mathrm{G}_{2}$ & $2 \cdot 3 \quad(1 \cdot 2-4 \cdot 3)$ & $1 \cdot 5 \quad(0 \cdot 8-3 \cdot 1)$ & 3.91 & $<0.01$ \\
\hline $\mathrm{G}_{3}$ & $0.84(0.42-1 \cdot 7)$ & $0.69(0.42-1 \cdot 13)$ & $2 \cdot 63$ & $<0.05$ \\
\hline $\mathrm{G}_{4}$ & $0 \cdot 2 \quad(0 \cdot 1-0 \cdot 8)$ & $0.2 \quad(0 \cdot 1-0 \cdot 4)$ & & NS \\
\hline \multicolumn{5}{|c|}{ Age 5 to 6.99 years: } \\
\hline Total IgG & $9 \cdot 7 \quad(6 \cdot 7-14 \cdot 1)$ & $9 \cdot 05(6 \cdot 7-12 \cdot 2)$ & & NS \\
\hline $\mathrm{G}_{1}$ & $6 \cdot 0 \quad(3 \cdot 8-9 \cdot 6)$ & $6 \cdot 27(4 \cdot 5-8 \cdot 8)$ & & NS \\
\hline $\mathrm{G}_{2}$ & $2 \cdot 5 \quad(1 \cdot 3-4 \cdot 8)$ & $1 \cdot 72(1 \cdot 0-3 \cdot 1)$ & 3.87 & $<0.01$ \\
\hline $\mathrm{G}_{3}$ & $0 \cdot 76(0.33-1 \cdot 74)$ & $0.73(0.4-1.35)$ & & NS \\
\hline $\mathbf{G}_{4}$ & $0 \cdot 2 \quad(0 \cdot 03-1 \cdot 7)$ & $0 \cdot 2 \quad(0 \cdot 1-0 \cdot 4)$ & & NS \\
\hline
\end{tabular}

\section{Results}

Values for boys and girls in the control group were similar for all subclasses and for total IgG.

Concentrations of $\mathrm{IgG}_{1}, \mathrm{IgG}_{2}, \mathrm{IgG}_{3}$ and total $\mathrm{IgG}$ were lower in asthmatic children aged 1 to 2.99 and 3 to 4.99 years when compared with age matched controls. $\mathrm{IgG}_{2}$ values were also lower in asthmatics aged 5 to 6.99 years $(\mathrm{p}<0.05)$ (table 1 , figure).

Twenty eight asthmatic children had one or more values more than two standard deviations below the mean for age matched controls. Twenty six had $\mathrm{IgG}_{2}$ deficiency-alone in 13 , and combined with total IgG deficiency in nine, $\operatorname{IgG}_{1}$ and total in two, $\operatorname{IgG}_{3}$ in one, and $\mathrm{IgG}_{3}$ and total in one. One child had a low concentration of IgG with subclass concentrations within the normal ranges, and a further child had IgG and $\mathrm{IgG}_{1}$ deficiency.

These 28 children with deficiencies, when compared with the remainder of the asthmatic group, were significantly younger and fewer had high IgE concentrations than the remainder. There were no significant differences in sex, age of onset, concomitant atopic disease, requirement for inhaled steroids, or skin test reactivity. Five children, all of whom had $\mathrm{IgG}_{2}$ deficiency, also had IgA deficiency (table 2).

\section{Discussion}

Our results indicate that IgG subclass deficiency, predominantly $\mathrm{IgG}_{2}$, is present in over one third of children under 7 with serious asthma. Five children 


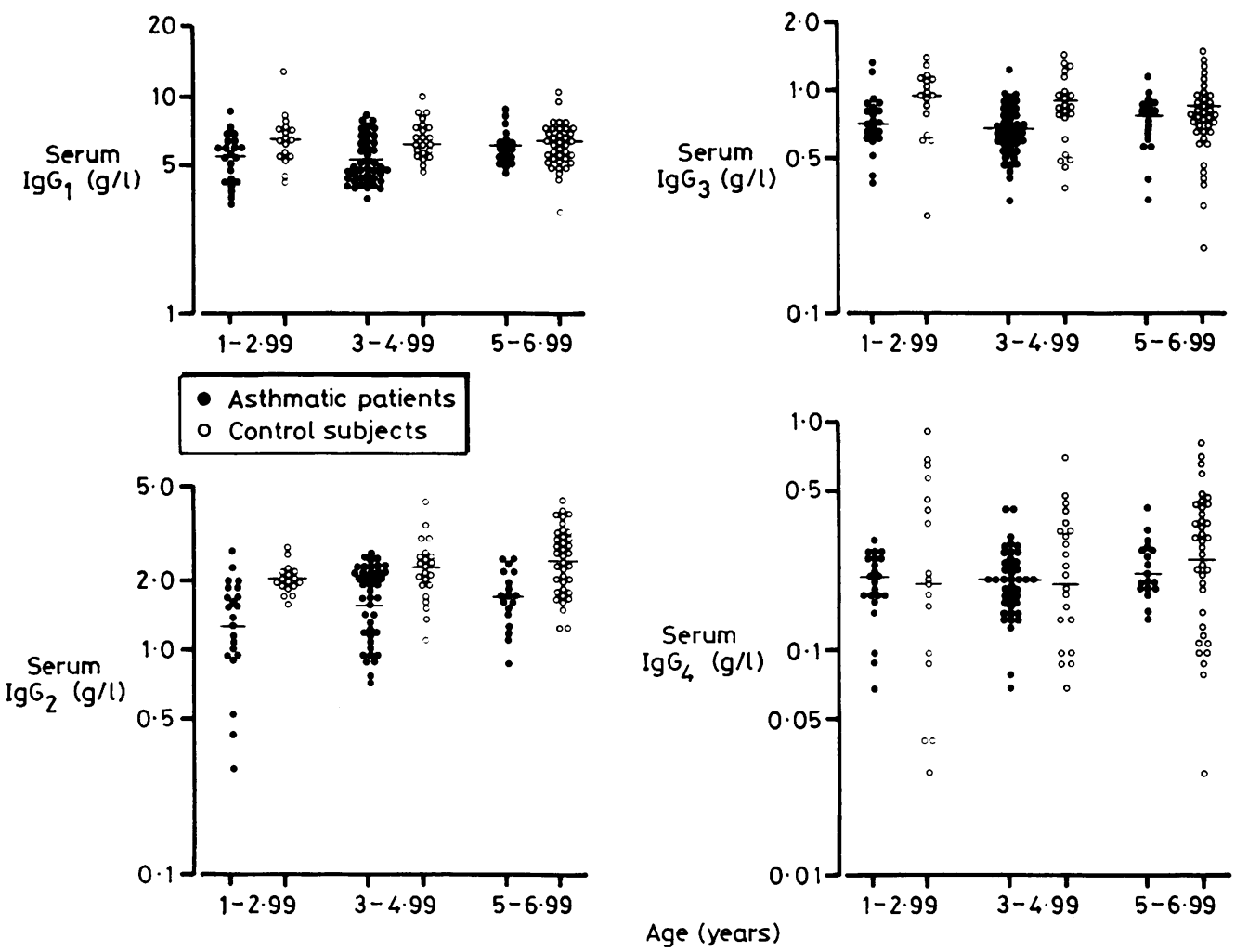

Figure Individual values for IgG subclasses in asthmatic and control patients. The mean of each group is indicated.

Table 2 Comparison of asthmatics with at least one deficiency of $\operatorname{IgG}$ or subclass and the rest of the study group

\begin{tabular}{|c|c|c|c|}
\hline & $\begin{array}{l}\text { Those with } \\
\text { at least } \\
\text { one deficiency } \\
(n=28)\end{array}$ & p Value & $\begin{array}{l}\text { Those with } \\
\text { no } \\
\text { deficiencies } \\
(n=54)\end{array}$ \\
\hline $\begin{array}{l}\text { Mean (SD) age } \\
\text { (months) }\end{array}$ & $36 \cdot 4(16 \cdot 4)$ & $<0.05$ & 47.8 (SD 14.9) \\
\hline $\begin{array}{l}\text { No }(\%) \text { of boys } \\
\text { Age at onset: }\end{array}$ & $22(79)$ & NS & $34(63)$ \\
\hline $\begin{array}{l}\text { No }(\%) \text { under the } \\
\text { age of } 1 \text { year } \\
\text { No (\%) between }\end{array}$ & $12(43)$ & NS & $24(44)$ \\
\hline $\begin{array}{l}1 \text { and } 2 \text { years } \\
\text { No (\%) receiving }\end{array}$ & $10(36)$ & NS & $23(43)$ \\
\hline $\begin{array}{l}\text { treatment with } \\
\text { inhaled steroids }\end{array}$ & $16(57)$ & NS & $22(40)$ \\
\hline No (\%) with rhinitis & $15(54)$ & NS & $32(59)$ \\
\hline No (\%) with eczema & $13(46)$ & NS & $25(46)$ \\
\hline $\begin{array}{l}\text { No (\%) with positive } \\
\text { skin tests } \\
\text { No }(\%) \text { with raised }\end{array}$ & $17 / 24$ & NS & $38 / 45(85)$ \\
\hline $\begin{array}{l}\text { IgE concentration } \\
\text { No (\%) with IgA }\end{array}$ & $17(61)$ & $<0.05$ & $49(91)$ \\
\hline deficiency & $5(18)$ & NS & 0 \\
\hline
\end{tabular}

had abnormally low concentrations of $\operatorname{IgA}$, and they all had concomitant $\operatorname{IgG}_{2}$ deficiency. Total IgG deficiency has been reported in children taking oral steroids ${ }^{6}$; none of our chldren were taking oral steroids when studied, though many had received short courses previously. Multiple IgG subclass deficiency was present only in younger patients.

In the previous study of IgG subclasses in children with asthma, $\operatorname{IgG}_{2}$ deficiency was noted in 10 of 37 'non-allergic children with chronic chest symptoms'; these children had negative skin tests and normal IgE concentrations. ${ }^{2}$ In our study negative skin tests and normal concentrations of IgE were more common in children with deficiencies. These children were significantly younger, however, and because the incidence of positive skin tests increases with age, ${ }^{7}$ the apparent association of $\mathrm{G}$ subclass deficiency and 'non-allergic' asthma may only be a reflection of a younger age group.

Atopic diseases including asthma have been linked with $\operatorname{IgA}$ deficiency, ${ }^{8}$ defective yeast opsonising activity, ${ }^{9} \mathrm{C} 2$ deficiency, ${ }^{10}$ and now IgG subclass deficiency. No specific immunodeficiency is accepted 
as predisposing to childhood asthma but the association with a variety of abnormalities indicates that some form of dysregulation of immunity may be concerned in the pathogenesis. It has been suggested that defects of the immune system that affect exclusion or elimination of antigen could be relevant in early infancy at the time of first presentation of antigen to cells making $\mathrm{IgE}^{11}$; clearance of adsorbed antigen might be impaired in IgG subclass deficiency.

The IgG antibody response to bacterial polysaccharide antigen resides mainly within $\mathrm{IgG}_{2}$ subclass $^{12}$ and the antibody response to some viruses may also be restricted to a particular subclass. ${ }^{13}$ Inability to mount an adequate $\mathrm{IgG}$ response might provoke or exacerbate asthma in certain children. Respiratory infection, particularly when viral, results in an increase in bronchial reactivity. ${ }^{14}$ Perhaps protracted infection and epithelial damage enhances this effect on airway function.

Our results show that IgG subclass concentrations are significantly reduced in young asthmatics. The hypothesis that IgG subclass deficiency predisposes to asthma depends on showing that the abnormalities predate the disease. We cannot be sure that the observed deficiencies were not a consequence of asthma or its treatment, but multiple deficiencies were present only in the younger children. This suggests some type of delayed maturation and tends to favour the concept that these deficiencies are primary.

A L-Y was supported by the Michael McGough Foundation for the Study of Liver Disease in Children, whom we also thank for providing our normal control subjects. We thank Angela McPherson for typing the manuscript.

\footnotetext{
References

1 Umetsu DT, Ambrosino DM, Quinti I, Siber GR, Geha RS. Recurrent sinopulmonary infection and impaired antibody
}

response to bacterial capsular polysaccharide antigen in children with selective IgG subclass deficiency. $N$ Engl J Med 1985;313: 1247-51.

2 Smith TF, Morris EC, Bain RP. IgG subclasses in nonallergic children with chronic chest symptoms. J Pediatr 1984;105: 896-900.

${ }^{3}$ Shackleford PG, Granoff DM, Nahm MY, et al. Relation of age, race, and allotype to immunoglobulin subclass concentrations. Pediatr Res 1985;19:846-9.

4 Buckley RM, Dees SC, O'Fallon WM. Serum immunoglobulins 1. Levels in normal children and in uncomplicated childhood allergy. Pediatrics 1968;41:600-6.

5 Aucouturier P, Mounir S, Preud'homme JL. Distribution of IgG subclass levels in normal adult sera as determined by a competitive enzyme immunoassay using monoclonal antibodies. Diag Immunol 1985;3:181-96.

${ }^{6}$ Berger W, Pollock J, Kiechel F, Dunning BA, Pearlman DS. Immunoglobulin levels in children with chronic severe asthma. Ann Allergy 1978;41:67-74.

${ }^{7}$ Morrison-Smith J. Skin tests and atopic allergy in children. Clin Allergy 1973;3:269-75.

${ }^{8}$ Taylor B, Norman AP, Orgel MA, Stokes CR, Turner MW, Soothill JF. Transient IgA deficiency and pathogenesis of infantile asthma. Lancet 1973;ii:111-3.

${ }^{9}$ Richardson VF, Larcher VF, Price JF. A common congenital immunodeficiency predisposing to infection and atopy in infancy. Arch Dis Child 1983;58:799-802.

10 Turner MW, Mowbray JF, Harvey BAM, Brostoff J, Wells RS, Soothill JF. Defective yeast opsonisation and $\mathrm{C} 2$ deficiency in atopic patients. Clin Exp Immunol 1978;34:253-9.

1 Soothill JF. Some intrinsic and extrinsic factors predisposing to allergy. Proceedings of the Royal Society of Medicine 1976;69: 439-42.

12 Siber GR, Schur PH, Aisenberg AC, et al. Correlation between serum IgG2 concentrations and the antibody response to bacterial polysaccharide antigens. $N$ Engl J Med 1980;303: 178-82.

13 Walker L, Johnson GD, MacLennan ICM. The IgG subclass response of human lymphocytes to B cell activators. Immunology 1983;50:269-72.

14 Empey DW, Laitinen LA, Jacobs L, et al. Mechanisms of bronchial hyper-reactivity in normal subjects after upper respiratory tract infection. Am Rev Respir Dis 1976;113:131-9.

Correspondence to Dr J F Price, Department of Child Health, King's College Hospit -1 , Denmark Hill, London SE5 8RX.

Accepted 4 May 1988 